\title{
Outpatient Pediatric Special Care. Developing health policies at the primary level of care
}

\author{
Pablo Justich, M.D. ${ }^{a}$, Pablo Cafiero, M.D. ${ }^{b}$, Anibal Bordón, M.D. ${ }^{c}$, \\ Diego Marquiani, M.D. ${ }^{c}$, Pablo Manjarin, M.D. ${ }^{d}$ and M. Rosario Williams, M.D. ${ }^{c}$
}

\begin{abstract}
In 1978, the World Health Organization defined primary health care as the cornerstone of global health. In recent years, the usual causes of mortality (infections, deficiency diseases) now include chronic and degenerative diseases. It is now possible to provide tertiary care to patients without adequate resources for their survival after discharge. The health system has not been able to adapt to such change and has maintained a fragmented, reactive, disease-centered model. "Selective primary care" is useful to redirect primary care bases according to the characteristics of the population. A set of specific measures, targeted at a population with specific vulnerabilities, leverages the power of primary health care. Here we describe the "Outpatient Pediatric Special Care" model of care implemented at the Center for Health and Community Action no. 5, in the Autonomous City of Buenos Aires.

Key words: primary health care, child care, public health policies, chronic diseases, follow-up.
\end{abstract}

http: / / dx.doi.org/10.5546/ aap.2019.eng.e606

To cite: Justich P, Cafiero P, Bordón A, Marquiani D, et al. Outpatient Pediatric Special Care. Developing health policies at the primary level of care. Arch Argent Pediatr 2019;117(6):e606-e625.

\section{INTRODUCTION}

"Health for All by the Year 2000." This was a well-known utopia, but it paved the way. The Alma-Ata Declaration provided guidance: primary health care (PHC) as the cornerstone of global health. ${ }^{1}$ The reformulation of certain objectives, centered on equity, social justice, and solidarity as basic new conditions of a novel strategy, was closely related to necessary and expected changes in pediatrics. $^{2}$
Since then, social, economic, cultural, and epidemiological changes have taken place that significantly modified the transition of health; as a result, new challenges that need to be faced have emerged. The rapid advances in knowledge and technology have helped to reduce mortality in relation to extreme prematurity, complex congenital heart diseases, tumors, etc.; however, the so-called "new morbidities" have then emerged as a result of such survival. These morbidities have turned into chronic conditions, with a major impact on health, and this has also left patients with associated vulnerabilities (housing, financial, cultural conditions, etc.) even more exposed.

This situation was perceived clearly at the Center for Health and Community Action (Centro de Salud y Acción Comunitaria, CeSAC) no. 5. It is worth mentioning some characteristics of the population seen at this facility: it is located in a "critically" vulnerable area; ${ }^{3}$ most people live below the poverty line and have unmet basic needs (UBNs), with no access to clean running water or sewer systems, a poor environmental sanitation, etc. The CeSAC no. 5 is located in an urban neighborhood in Community 8 of the Autonomous City of Buenos Aires (CABA), with a high rate of several generations of migrant population. Together with other neighborhoods, Community 8 is in the group with the highest socioeconomic exclusion levels in a city that, paradoxically, flaunts the highest per capita income nationwide. In Community 8 , the mortality rates and the public health coverage contrast with the 
indicators registered in CABA (Table 1). The coexistence of such contrasting scenarios leads to an epidemiological polarization phenomenon, ${ }^{4}$ where the first and third stages of epidemiological transition coexist and overlap. The same region accommodates cohorts with a high mortality rate due to infections (many of which are preventable), deficiencies, a high infant mortality rate (IMR), and a low life expectancy at birth (LEB), together with another group with a higher mortality rate due to chronic and degenerative diseases, a low IMR, and a high LEB. In turn, there are tertiary care facilities with sufficient resources to provide care for complex pediatric conditions, capable of reducing neonatal and infant mortality, but which discharge high-risk patients (with various types of sequelae, polypharmacy and/or technology care requirements) into a setting with inadequate socioeconomic and housing resources for their survival. A clear example are extreme preterm infants that survive thanks to a very good perinatal care who, after weeks of receiving complex care, face situations with profound personal and nutritional deficiencies, severe weather conditions, multiple risk factors for acute lower respiratory tract infections (ALRTIs), insufficient support from the Public Health System (PHS), etc. In addition to their high biological vulnerability, they suffer an extensive socioeconomic vulnerability. The PHS, as such, has not been able to adapt to this change and has maintained a fragmented, reactive, diseasecentered model.

For years, the pediatricians working at the CeSAC no. 5 have coped with this health problem. This health care approach was split between walk-in appointments assigned in the same day and scheduled appointments. Patient access was determined by the health care team possibilities, order of arrival, and assignment of appointments. The population was forced to adapt to this model. The parents of these patients, who have greater care demands and vulnerabilities, had to "compete" with the rest to ensure care for their children. Their possibilities were usually impaired; their demands were rejected or they were forced to accept off-schedule appointments that could not always be met.

\section{PLANNING A NEW APPROACH: Selective Primary Care}

In 1999, in a health care center located in one of the poorest neighborhoods of CABA, Mario Rípoli, M.D., established a new essential tool in his work: "selective primary care," ${ }^{\prime 5}$ which helped to redirect the bases of PHC according to the characteristics of the population. A set of specific measures, targeted at a population with specific vulnerabilities, leveraged the power of PHC. Without leaving primary prevention and the "comprehensive" action model aside, "selective" measures adapted to the prevalent disease were proposed, especially for highly vulnerable groups, together with secondary and tertiary prevention measures. This way, the advantages of PHC complemented the effectiveness of selective models.

Given that "exceptional" circumstances had become usual, it was decided to adopt a new approach: indiscriminately assigning off-schedule appointments was not enough; it was necessary to tackle a complex problem from a broad and proactive perspective, with formal and informal

TABle 1. Comparison between the Autonomous City of Buenos Aires and Community 8. Demographic, social, and health indicators

\begin{tabular}{lcc}
\hline Indicator & CABA & Community 8 \\
\hline Total population & 3059122 inhab. & 225737 inhab. \\
Rate of natural increase & 2.7 & 8.7 \\
Overcrowding & $8.70 \%$ & $17.20 \%$ \\
"Critical" overcrowding & $1.30 \%$ & $3.80 \%$ \\
Households with income $<$ total basic basket & $25 \%$ & $54.30 \%$ \\
Single public health coverage & $20 \%$ & $49.60 \%$ \\
IMR per 1000 LBs & 7.2 & 9.7 \\
IMR due to reducible causes & 4 & 6.7 \\
IMR due to hardly reducible causes & 2 & 1.1 \\
NMR & 5.4 & 5.8 \\
PNMR & 1.8 & 3.9 \\
Average age at death - Males (years old) & 73.6 & 66.2 \\
Average age at death - Females (years old) & 81 & 75 \\
\hline
\end{tabular}

Source: Statistical Yearbook 2016 - General Department of Statistics, Surveys and Censuses, Government of the Autonomous City of Buenos Aires. CABA: Autonomous City of Buenos Aires; IMR: infant mortality rate; LBs: live births;

NMR: neonatal mortality rate; PNMR: post-neonatal mortality rate. 
resources that would allow to cross the borders existing among and within the different levels of care.

The main objective of such approach was to minimize the rejection of high-risk patients and centralize care by bringing the different levels of care closer. The objectives also included reducing the redundant transit among facilities by rapidly identifying risk situations to take more timely measures.

Health is determined at different levels, so our response needed to be systemic and multidimensional:

- Social determination: recognizing socioeconomic characteristics and integrating measures with social services provided by the health care team, maintaining a closer contact with patients and their reality and establishing a greater compliance with follow-up. In addition, collaborating with the application for allowances, benefits or pensions, if applicable.

- Institutional/health system determination: due to the scarce organization and the lack of system coordination, an attempt was made to warrant permanent access, in addition to the management of appointments at the different levels of care (specialist consultations, ancillary tests, etc.) by simplifying access to appointments. A complete survey of diseases associated with groups of high IMR by age and cause was carried out to establish their relation to the PHS. The project sought to bring the system closer to patients with chronic conditions or sequelae, who showed a high dependence on the system and greater access difficulties. ${ }^{6,7}$

- Biological determination: working with patients based on their characteristics to reduce their risks (nutritional risks, immunizations, early detection of diseases or sequelae, follow-up of connatal infections, early care of genetic disorders, etc.).

From the beginning, it was observed that this approach could not be handled only by the Department of Pediatrics; instead, it was necessary for the health care team to work in a transdisciplinary manner and to incorporate decisions among the different disciplines of the team (Social Services, Anthropology, Mental Health, Nutrition, Pediatrics, Nursing, etc.). Our "special" patients corresponded to all these disciplines and a network-like operation was necessary to engage, integrate, and protect them.

\section{METHOD}

The problem was addressed based on the "Langley enhancement model." 8 Problems to be solved were the basis for planning; initial measures based on such planning were carried out; results were analyzed and actions were taken upon them. Such dynamic approach allowed to improve the process on an ongoing basis (plando-analyze-act cycle). We required a resilient and innovative response.

\section{POPULATION, RESOURCES, TOOLS, AND FIRST STEPS}

\section{- Population}

The population of Community 8 (CABA) was 187237 inhabitants (National Household Survey 2010); of them, 59363 (31.7\%) were children. ${ }^{9}$ The estimated population of Villa 15 (one of the clusters with the highest population density in the Community) was more than 30000 inhabitants (due to housing irregularities, such estimation was based on historical demographic data). As per our current records, 9745 inhabitants are younger than 18 years, including this neighborhood. And there is a number of patients that cannot be estimated that come from surrounding neighborhoods and Greater Buenos Aires, which is adjacent to Community 8 .

\section{- Physical resources}

The CeSAC no. 5, located in Villa Lugano of Community 8 (CABA), was moved to its new location in 2004. It has a surface area of $1230 \mathrm{~m}^{2}$, 35 medical offices, 2 dental offices, a laboratory sample collection room, an immunization room, a pharmacy, an X-ray room, an ultrasound room, and a teaching room (source: CeSAC no. 5).

\section{- Human resources}

In 2015, the CeSAC workforce included 70 employees (both health care providers and nonprofessional staff), as detailed in Annex 1 (Spanish version).

\section{- Development and implementation of an} outpatient pediatric special care model

Initially, participants for inclusion in the health care model were defined. First of all, diagnoses strongly associated with infant mortality were included. ${ }^{10}$ Secondly, patients with chronic diseases and a high need for contact with the PHS were considered. Risk groups and inclusion criteria were defined (Table 2). The health care team was informed so that every patient that met the criteria was referred to the program officers for their inclusion and, thus, to engage the largest number possible of the target population. A 
database was designed; it included demographic data, diagnoses, date of inclusion, latest visit and next appointment, discharge date, and reason for discharge (discharge, death, transfer, etc.). A specially designed medical record was developed (Annex 2 Spanish version) and incorporated in a separate file available at the department. Every patient susceptible to admission into the model was interviewed, the reasons for inclusion, benefits, and liabilities were explained, and they were asked for their consent to participate. One hundred per cent of patients agreed to participate. (An informed consent was not requested because the project did not imply changes in patient care or the dissemination of information outside the CeSAC). The policy for access to care was defined, and appointments were reorganized so that care was warranted to our patients in $100 \%$ of contacts with the CeSAC. Once included, they were able to access the center any time they requested it by identifying themselves as "Outpatient Pediatric Special Care" (OPSC) patients at the reception desk. Appointments at the second level of care were also coordinated to meet different medical needs (Pediatric Neurology, Preterm Infant Follow-up, Day Hospital, Hospitalization, Ancillary Tests, Special Immunizations, etc.). The entire health care team, including nurses, pharmacists, social workers, general practitioners, nutritionists, administrative staff, etc., had an active participation by alerting on inclusion criteria and changing the approach to these patients. This enabled a rapid adaptation to specific circumstances, such as the provision of drugs and newborn formula, the immediate identification of risk groups for immunization in epidemic outbreaks (e.g., H1N1 flu in 2009), among others.

Once the program organization was completed, the different management levels were informed: CeSAC Management, Department of Pediatrics, and Hospital Santojanni Management. During subsequent visits, the authorities of the Department of Health were also informed, and the project was made public. The response at these levels was favorable.

In March 2004, health care under the OPSC modality started being provided.

\section{EXPERIENCE AND OUTCOMES}

Between 2005 and 2018, an average of 37787 total visits / year $( \pm 6348.66)$ took place at the CeSAC no. 5; $20464( \pm 3191.6)$ of these corresponded to pediatric visits/year. Pediatric visits accounted for $54.16 \%$ of total visits. Since its launch in March 2004 until January 2019, 946 patients were seen under the OPSC modality: 559 $(59.1 \%)$ were males and $387(40.9 \%)$, females. In turn, these patients were classified into 6 groups (Table 3).

The table also shows the number of patients per group admitted in that period. Figure 1 shows the rate of patient inclusion in the first weeks. In this 15-year period, 201 patients were discharged from

TABLE 2. Inclusion criteria for the Outpatient Pediatric Special Care program (at the time of its launch in 2004)

\section{Inclusion criteria}

- Children born at a gestational age of less than 37 weeks and with a current chronological age younger than 6 years.

- Children younger than 1 year and born with a birth weight of less than $2500 \mathrm{~g}$.

- Children with moderate to severe neurological development disorders, based on clinical criteria.

- Children with connatal infections in the process of diagnosis, treatment or sequelae management.

- Children with genetic disorders or congenital abnormalities that require ongoing follow-up.

- Children with organ transplant, cancer, chronic kidney disease, rheumatic disease, chronic pulmonary disease, cardiovascular disease or requiring neurosurgery.

TABLE 3. Distribution by group at the time of admission to the program (2004-2019)

\begin{tabular}{lcc}
\hline & Patients & Proportion \\
\hline Group 1 (clinical conditions) & 246 & $26 \%$ \\
Group 2 (surgical conditions) & 60 & $6.34 \%$ \\
Group 3 (genetic, congenital, and metabolic conditions and skeletal dysplasias) & 113 & $11.95 \%$ \\
Group 4 (neurological and neurodevelopmental disorders) & 267 & $28.22 \%$ \\
Group 5 (cancer and organ transplant) & 13 & $1.37 \%$ \\
Group 6 (risk and preterm newborn infants) & 247 & $26.11 \%$ \\
\hline
\end{tabular}


the program: $101(51.24 \%)$ because they turned 18 years old; of them, 38 were in group 4 . Among those who were preterm infants, $93(46.26 \%)$ were discharged at 6 years old without sequelae and 39 were transferred to group 6. A total of $7(3.48 \%)$ were dropouts or deceased patients.

There are currently 743 active patients in the OPSC program distributed into the 6 groups mentioned above, as shown in Table 4; examples of diseases receiving follow-up are also described (Annex 3 Spanish version).

As seen when comparing the distribution by group at the time of admission and that of active patients, many were transferred from a group of high incidence (group 6) to a group of high prevalence (group 4) due to prematurityrelated morbidity, which has a high impact on our population.
The definition of criteria to assess results was attempted from the beginning. Treatment compliance, variations in the Z-score for weight or height, etc. were not used due to the heterogeneity in terms of disease and population. The positive indicators of this model were its generalized acceptance for adoption, the very high rate of compliance with the national immunization schedule, the lack of significant rejections, and that there were no formal claims about the program quality or compliance in the studied period.

\section{A NEW GENERATION OF PHYSICIANS. TOWARDS A NEW PARADIGM}

The teaching experience at the CeSAC no. 5 is extensive. It hosts graduate students who are taking Pediatrics as part of the Clinical course of

TABLE 4. Distribution of active patients as of January 2019

\begin{tabular}{lccc}
\hline & Patients & Proportion & Age (mean \pm SD) \\
\hline Total & 743 & $100 \%$ & 9.7 years old $( \pm 4.52)$ \\
Group 1 & 221 & $29.74 \%$ & 10.85 years old $( \pm 4.16)$ \\
Group 2 & 60 & $8.08 \%$ & 9.32 years old $( \pm 4.44)$ \\
Group 3 & 99 & $13.32 \%$ & 9.84 years old $( \pm 4.55)$ \\
Group 4 & 268 & $36.07 \%$ & 10.52 years old $( \pm 4.22)$ \\
Group 5 & 10 & $1.35 \%$ & 10 years old $( \pm 5.44)$ \\
Group 6 & 85 & $11.44 \%$ & 4.26 years old $( \pm 1.48)$ \\
\hline
\end{tabular}

SD: standard deviation.

FIGURE 1. Evolution of admissions to the OPSC program by week, since initiation to week 30. Number of patients, by week and accumulated

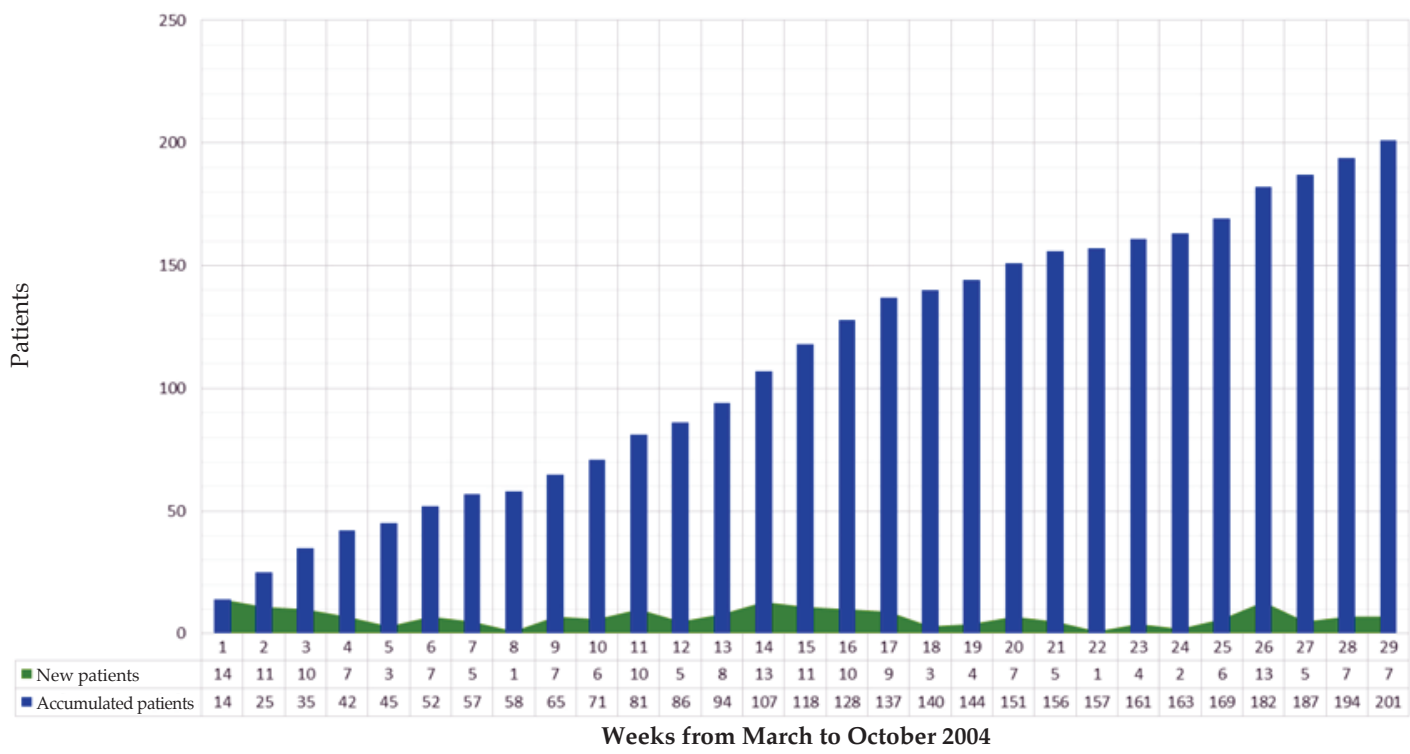

OPSC: Outpatient Pediatric Special Care. 
the School of Medicine and rotating interns from the Annual Rotating Internship (Universidad de Buenos Aires, UBA), as well as pediatric residents and attending physicians from different national and CABA hospitals, workers' unions health insurance organizations and private hospitals. ${ }^{11,12}$

The objective of such rotating internships is to learn, on the field, the integrated concept of the health-disease dyad as a dynamic process conditioned by social, environmental, cultural, and family factors. Emphasis is placed on preventive and health promotion aspects. These guidelines are defined in Section 40 of the Health Law of CABA, Ordinance 40997 / 86, as amended, the syllabus of Pediatrics from the graduate program, and the reference framework of the pediatric residency program. ${ }^{13-16}$

Rotating interns participate in patient care as part of the OPSC program, and this allows them to understand the care of high-risk patients in previously unknown situations, thus redefining the role of PHC, not only as a simple form of medicine but also as a relevant, integrated part of the PHS. This includes specific health care experience and strategic thinking in PHC. ${ }^{17-19}$

The teaching experience with residents and students created awareness of the necessary reconciliation between the theory of prevalent problems and the complex reality of our population.

\section{CURRENT SITUATION}

\section{Strengths, weaknesses, opportunities and threats analysis}

The progress of the model was analyzed in 2 assessment stages: 2005 and 2013. This allowed to adjust inclusion criteria, clear databases, and improve the health care approach. The current situation was assessed based on a strengths, weaknesses, opportunities, threats (SWOT) analysis (Table 5).

\section{DISCUSSION \\ Programs, plans or policies}

In recent decades, several plans and programs have been implemented aimed at solving different health problems. Most of them were imposed from central levels in a vertical and parallel manner, leaving community involvement aside and with a lack of coordination among them. ${ }^{20}$ Organizational fragmentation, with coexistent sub-systems that were not coordinated or integrated, increased costs due to duplications and transactions, which resulted in a varied quality in terms of provision..$^{21}$ This was due to the absence of a rational, planned, integrated, wellexecuted, patient-centered NHS with community involvement. As an answer to these problems, the concept was modified to the establishment of health networks. ${ }^{22}$

TABLE 5. Current situation of the Outpatient Pediatric Special Care program. SWOT analysis

INTERNAL analysis
Strengths
- Human resources with a high level of training.
- Positive attitude towards a challenge with a greatly
cohesive staff.
- Comprehensive care, transdisciplinary approach.
- Knowledge of the population.
- Building resources and adequate equipment.
- Affordable.

\section{Weaknesses}

- Limited coordination with other levels of care.

- Lack of projection to other health centers.

- Limited hours with specially designated staff.

- Administrative limitations for data and statistics entry.

- Reduced availability of hours for care provision due to the administrative tasks inherent to the program.

\section{Opportunities}

- Extended coverage and accessibility (null rejections).

- Adequate social acceptance.

- Community involvement.

- Multiplying effect of other measures and policies.

- Rapid recognition and identification of the target population.

- Likely synergy with integrated health care networks (redes integradas de servicios de salud, RISS).

- On-site teaching with complex realities.

Threats

- Rigidity at other levels of care to accept the new policy and the program.

- Lack of drive in relation to the health administration.

- Difficult relationship with the different care and health management levels due to the program's local nature. 
In the past decade, the World Health Organization (WHO) has disseminated a new concept in this regard. Turning current systems into integrated health care networks (redes integradas de servicios de salud, RISS), understood as an "integrated network of equal and comprehensive health care services for a specific population willing to account for its clinical and economic outcomes and the health status of the population it serves." ${ }^{23}$ This concept surpasses that of health networks because it focuses on a comprehensive functioning and is based on PHC systems that improve access, equity, quality, and effectiveness to provide the population with favorable responses. A practical example to understand the idea is the "health care model for people with chronic diseases (HCMPCD)," which has established a national strategy to address a new epidemiological reality in a comprehensive manner based on PHC and in coordination with the different levels of care. ${ }^{24}$ This constitutes a new paradigm for Argentina, where the health care system works, most of the time, contrary to how a network functions.

Based on this experience, the tendency is believed to go towards the replacement of autonomous programs by actual policies and an effective and rational organization that governs health.

The OPSC program was created in the same line with RISS and, therefore, as in the case of the HCMPCD model, it may be implemented as a policy within the system, boosted by the information tools provided by the new proposal. The OPSC is a health policy. It establishes a targeted health care model based on the risk for mortality and provides a wider framework for the epidemiological surveillance of pediatric health in each geographic unit. The CeSAC functions as the gateway and also as the main coordinator of patient care.

\section{New challenges}

Health care dynamics should go along with social and epidemiological dynamics. In this changing reality, resources should be implemented in addition to technological advances. The integration of electronic medical records, telemedicine, teaching manikins, etc. may help to develop a better PHC. ${ }^{25}$

The information should focus on patients and their setting, and on identifying risk groups, generating priorities, establishing alerts and reminders that activate actions among the different disciplines for their interaction, developing recommendations, and promoting communication among the health system actors.

\section{Weaknesses}

The lack of an adequate information support and the possibility of keeping it updated hindered the presentation of more detailed statistical analyses. Future assessments are required for their development.

\section{CONCLUSIONS}

Recognizing children at risk, identifying them, supervising their care, ensuring universal access and an adequate coordination with other disciplines and the different levels of care seems to be the most direct path towards the reduction of infant mortality, an enhanced health promotion and protection, and, therefore, a more equitable society. The success of this mission lies in an organization with a consistent care and a clear knowledge of the health reality of our children.

\section{ACKNOWLEDGMENTS}

We would like to thank the staff from CeSAC no. 5, who made an effort to carry out this project; Graciela Spatz, M.D., and Alicia Cattaneo, B.S., for their generous and enhanced perspective; and Mario F. Rípoli, M.D., who started this process and this project with us and who fundamentally taught us to understand pediatric primary care in a humane, generous, and academically strict manner.

\section{REFERENCES}

1. OMS/UNICEF. Conferencia Internacional sobre Atención Primaria de Salud. Alma Ata, URSS: 6-12 de Septiembre 1978. [Accessed on: January 15 $\left.{ }^{\text {th }}, 2019\right]$. Available at: https: / / www.paho.org/hq/dmdocuments/2012/Alma-Ata1978Declaracion.pdf.

2. Ramonet M. Repensar y acordar los Objetivos de Salud Materno-Infantil en la reforma de la Atención Primaria de la Salud. Una propuesta desde la Pediatría. Arch Argent Pediatr. 2008; 106(6):486.

3. INDEC. Mapa: Variación relativa de la población por Comuna entre 1991 y 2010. Poblac B Aires. 2016; 13(23):20.

4. Frenk J. Transiciones: vidas, instituciones, ideas. Salud Pública Méx. 1997; 9(2):144-50.

5. Rípoli M. Atención Primaria Selectiva: Una experiencia pediátrica urbana. Buenos Aires: EUDEBA; 1999.

6. Cafiero P.Desarrollo infantily sus alteraciones. In Sociedad Argentina de Pediatría. PRONAP. 2008; 1:60-6.

7. Cafiero P. Puesta al día en discapacidad intelectual: Conceptos generales y aspectos diagnósticos. In: Jornadas Nacionales de Discapacidad en Pediatría. Del 2 al 4 de julio de 2015. Ciudad de Buenos Aires. [Accessed on: January $\left.15^{\text {th }}, 2019\right]$. Available at: https://www.sap.org.ar/docs/ congresos_2015/Discapacidad/cafiero.intelectual.pdf.

8. Langley GJ, Nolan KM, Nolan TW, Norman CL, et al. The 
improvement Guide: A practical approach to enhancing organizational performance. San Francisco: Jossey-Bass; 1996.

9. Dirección General de Estadísticas y Censos. Encuesta Nacional de Hogares 2010. Población total por sexo e índice de masculinidad, según en años simples y grupos quinquenales deedad, Comuna 8. Gobierno de la Ciudad de Buenos Aires. [Accessed on: August $8^{\text {th }}, 2018$ ]. Available at: https: / / www.estadisticaciudad.gob.ar/eyc/ ?p = 46907.

10. Fondo de las Naciones Unidas para la Infancia. Resultados de la propuesta para el análisis de las muertes infantiles. In: ¿Por qué mueren los niños? Tres experiencias. Buenos Aires: UNICEF, 2000.Pages 45-56.

11. Cafiero P, Marquiani D, Rípoli M. Formación de residentes en el primer nivel de atención: Una experiencia de trabajo. Med Soc (En línea). 2010;1(1). [Discontinued publication. Article available through the corresponding author].

12. Abramzón M, Bonazzola P, Dubkin S, Findling L, et al. Las residencias del equipo de salud: Desafíos en el contexto actual. Buenos Aires: OPS, Secretaría de Salud, UBA, Instituto Gino Germani; 2003. [Accessed on: January $15^{\text {th }}$, 2019]. Available at: https://www.observatoriorh.org/sites/ default / files/webfiles/fulltext/resid_equipo_salud.pdf

13. Comisión Consultiva de Pediatría. Marco de Referencia para la formación en Residencias Médicas especialidad. Pediatría. Buenos Aires: Sistema Nacional de Residencias delEquipo deSalud. Dirección Nacional de Capital Humano y Salud Ocupacional. 2010. [Accessed on:January $17^{\text {th }}, 2019$ ]. Available at: http://www.msal.gob.ar/residencias/images/ stories/descargas/acreditaciones/adjuntos/pediatria.pdf.

14. Unidades Docentes y Académicas hospitalarias. Departamento de Pediatría. Facultad de Medicina-UBA. PIP Programa Integrado de Pediatría. [Accessed on: January $\left.17^{\text {th }}, 2019\right]$. Available at: https://www.fmed.uba.ar/ departamentos_y_catedras/departamento-de-pediatria / programa-de-la-materia.

15. Ciment G, Mendes Diaz A. Ecodesarrollo, calidad de vida y salud. Buenos Aires: Mimeo; 1984.

16. Bello J, De Lellis M. Modelo social de prácticas de salud. Comportamientos familiares para el cuidadoy recuperación de la salud. Un aporte a las intervenciones a nivel local. Buenos Aires: Proa XXI; 2001.

17. O'Donnell A, Carmuega E. Hoy y mañana. Salud y calidad de vida de la niñez argentina. Buenos Aires: CESNI; 1998.
18. Moreno E, Crivelli V, Kestelman N, Malé M, et al. Guía de programación local de actividades de salud materno infantil. Buenos Aires: Ministerio de Salud de la Nación; 2000.

19. Subcomisión de Acreditación de Residencias. Evaluación del primer ciclo de acreditación de residencias. Arch Argent Pediatr. 2001; 99(6):542-4.

20. La Red Comunitaria. In Dabas E, Casserly P, Lemus J. Salud Social y Comunitaria. Salud y Redes. Módulo 9:43. [Accessed on: August $\left.10^{\text {th }}, 2018\right]$. Available at: http://www.msal.gob.ar/ images / stories / bes / graficos / 0000001034 cnt-modulo_9_ salud-redes.pdf.

21. Roses M. Palabras de cierre. In "Conferencia internacional de salud para el desarrollo: derechos, hechos y realidades: de alma ata a la declaración del milenio: Buenos Aires 30/15". August $17^{\text {th }}, 2007$. Buenos Aires, Argentina.

22. Rovere M. Redes In Salud; Un Nuevo Paradigma para el abordaje de las organizaciones y la comunidad. Rosario: Secretaría de Salud Pública/AMR, Instituto Lazarte; 1999. [Accessed on: August 12 $2^{\text {th }}, 2018$ ]. Available at: http://www. saludcolectiva-unr.com.ar/docs/SC-121.pdf.

23. Organización Panamericana de la Salud. Redes Integradas de Servicios de Salud: Conceptos, Opciones de Política y Hoja de Ruta para su Implementación en las Américas. Washington D.C: OPS; 2010. Serie: La Renovación de la Atención Primaria de Salud en las Américas No. 4. [Accessed on: March 16 ${ }^{\text {th }}$, 2018]. Available at: https: / / www.paho.org/ uru / index.php?option=com docman\&view=download\&alias=213-aps-redesintegradas-servicios-salud-conceptos\&category_ docman\&view =download \&alias=213-aps-redesintegradas-servicios-salud-conceptos\&category_ slug=sistemas-y-servicios-de-salud\&Itemid=307.

24. González G, Laspiur S, L`Hopital C, Valenti L, et al. Abordaje integral de personas con Enfermedades Crónicas No Transmisibles modelo MAPECPrograma, orientaciones y recursos para el equipo docente. Ciudad Autónoma de Buenos Aires: Ministerio de Salud de la Nación; 2016. [Accessed on: March 16 ${ }^{\text {th }}, 2018$ ]. Available at: http:// msal.gob.ar/images/stories/bes/graficos/0000000905cntmapec_docentes_2016.pdf.

25. Fernández Ruiz Al. Haciendo el hoy, proyectandoel futuro. Med Infant. 2017; 24(4):360. 
e614 / Arch Argent Pediatr 2019;117(6):e606-e625 / Special article

\section{ANEXO 1}

Recursos humanos disponibles en el Centro de Salud y Acción Comunitaria N. ${ }^{\circ} 5$

\begin{tabular}{lcc} 
Personal & Cantidad & Condición \\
\hline Personal administrativo & 7 & \\
Técnica en Farmacia & 1 & \\
Enfermería & 1 & \\
Antropóloga & 2 & Personal estable \\
Farmacéuticas & 2 & \\
Nutricionistas & 2 & \\
Odontología & 1 & \\
Anatomía Patológica & 2 & \\
Obstetricia & 1 & \\
Psiquiatría & 7 & \\
Psicología & 5 & \\
Trabajadora social & 1 & \\
Psicopedagoga & 13 & Rotaciones trimestrales \\
Médicos pediatras & 3 & Rotaciones de formato variado \\
Médicos clínicos & 6 & \\
Médicos generalistas & 6 & \\
Médicos tocoginecólogos & 2 & 25 \\
Médicos ecografistas & 26 & \\
\hline Residentes de Pediatría & & \\
Otros residentes & & \\
\hline
\end{tabular}

Fuente: CeSAC N.ㅇ 5 (2014). 
ANEXO 2

H. C. No.:

Nombre y apellido:

Fecha dei 1. $\stackrel{\text { er }}{\text { control: }}$

Domicilio:

DNI:

Fecha de nacimiento:

Lugar de nacimiento:

Cobertura médica:

№. de afiliado:

Pediatra de cabecera:

Centro:

\section{Antecedentes perinatológicos:}

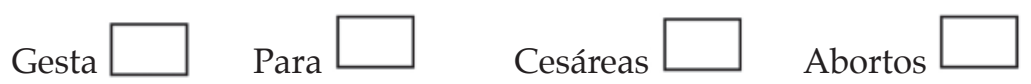

Embarazo controlado: sí/no Desde (fecha): / / Cantidad de controles:

Lugar de control:

Antecedentes: Hipertensión $\square \quad$ Diabetes $\square \quad$ Tabaco $\square \quad$ Fármacos/tóxicos $\square$

(Maternos) Traumatismos $\square \quad$ Cirugías $\square \quad$ Infecciones $\square$

Otros:

Antitetánica: $\square \quad$ Cantidad de dosis: .......... Duración del embarazo:

Serologías del embarazo:

$\operatorname{VDRL}(\quad) / /$

Toxopl. ( ) / /

Hepat. B( ) / / HIV ( ) / Chagas ( ) / /

Otras: 
e616 / Arch Argent Pediatr 2019;117(6):e606-e625 / Special article

\section{PARTO:}

Comienzo: espontáneo $\square$ inducido $\square \quad$ Lugar de nacim.: htal. .

Finalización: vaginal $\square$ forcipal $\square$ cesárea $\square$ Causas:

Presentación: cefálica $\square$ podálica $\square$ otras:

RN $(1) \quad$ EG

Ruptura de membranas

Liq. amniótico

Peso al nacer:

g Talla al nacer:

$\square \mathrm{cm}$

P. craneal: $\square \mathrm{cm}$

Apgar: /

Edad gestacional:

semanas

Alta:

Caída del cordón:

FEI: madre

Complicaciones:

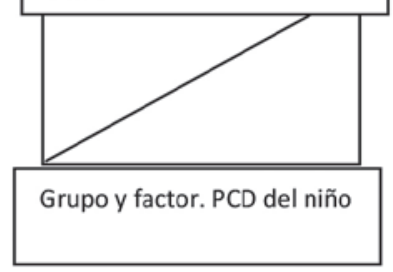

\section{Familigrama y antecedentes familiares:}

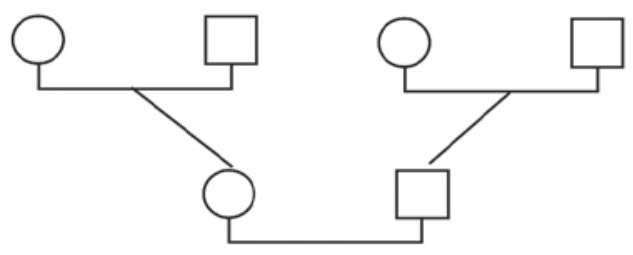

Enfermedades prevalentes

\begin{tabular}{l}
\hline $1-$ \\
\hline $2-$ \\
\hline $3-$ \\
\hline $4-$ \\
\hline
\end{tabular}

Antecedentes personales patológicos: 


\section{INMUNIZACIONES}

\begin{tabular}{|c|l|l|l|l|l|l|l|}
\hline Edad & BCG & Cuádruple & Doble & Sabin/Salk & Triple viral & Hepatitis B & Otras \\
\hline Al nacer & & & & & & & \\
\hline 2 meses & & & & & & & \\
\hline 4 meses & & & & & & & \\
\hline 6 meses & & & & & & & \\
\hline 12 meses & & & & & & & \\
\hline 18 meses & & & & & & & \\
\hline Ingr. escol. & & & & & & & \\
\hline 16 años & & & & & & & \\
\hline
\end{tabular}

\section{Alimentación:}

Lactancia exclusiva $\square$ Duración:

Alimentación artificial. $\square$ Tipo:

Alimentación complementaria. Edad de inicio:
Lactancia + complem.

Cantidad:

Vit. ACD $\square$ Desde:

Tipo de preparaciones:

Lugar: $\quad$ Casa $\square$ Guardería $\square$

Comedor barrial. $\square$

Caja:

\section{ANTROPOMETRÍA}

\begin{tabular}{|c|c|c|c|c|c|c|c|}
\hline \multicolumn{7}{|c|}{ Menores de 1 año } \\
Fecha & Edad & Peso P/E & \multicolumn{1}{l|}{ V.g/dia } & Talla & \multicolumn{1}{l|}{ T/E } & P.cef \\
\hline & & & & & & & \\
\hline & & & & & & & \\
\hline & & & & & & & \\
\hline & & & & & & & \\
\hline & & & & & & & \\
\hline & & & & & & & \\
\hline & & & & & & & \\
\hline & & & & & & & \\
\hline & & & & & & & \\
\hline & & & & & & & \\
\hline & & & & & & & \\
\hline & & & & & & & \\
\hline
\end{tabular}

\begin{tabular}{|c|c|c|c|c|c|c|c|c|}
\hline \multicolumn{8}{|c|}{ Mayores de 1 año } \\
Fecha & Edad & Peso & P/E Talla T/E Adec. P/T Vel. P Vel. T \\
\hline & & & & & & & & \\
\hline & & & & & & & & \\
\hline & & & & & & & & \\
\hline & & & & & & & & \\
\hline
\end{tabular}

\section{Criterio de ingreso:}

Fecha de ingreso al programa: 


\section{Derivado por el siguiente:}

\begin{tabular}{|c|c|c|c|c|c|c|}
\hline \multicolumn{2}{|c|}{ PATOLOGÍA RESPIRATORIA: } & \multicolumn{5}{|l|}{ sí - NO } \\
\hline Diagnóstico: & $\square \mathrm{SDRt}$ & $\square \mathrm{EMH}$ & & $\square \mathrm{NMN}$ & $\square$ SALAM & $\square$ HPPRN \\
\hline \multicolumn{7}{|l|}{ Otros: } \\
\hline Tratamiento: & $\square$ Halo: & días & $\square C P A P:$ & días & $\square$ ARM: & Máx. MAP: \\
\hline
\end{tabular}

Complicaciones: $\square$ NMTx $\square$ Est. laríngea $\square$ Atelectasia $\square$ Otros:

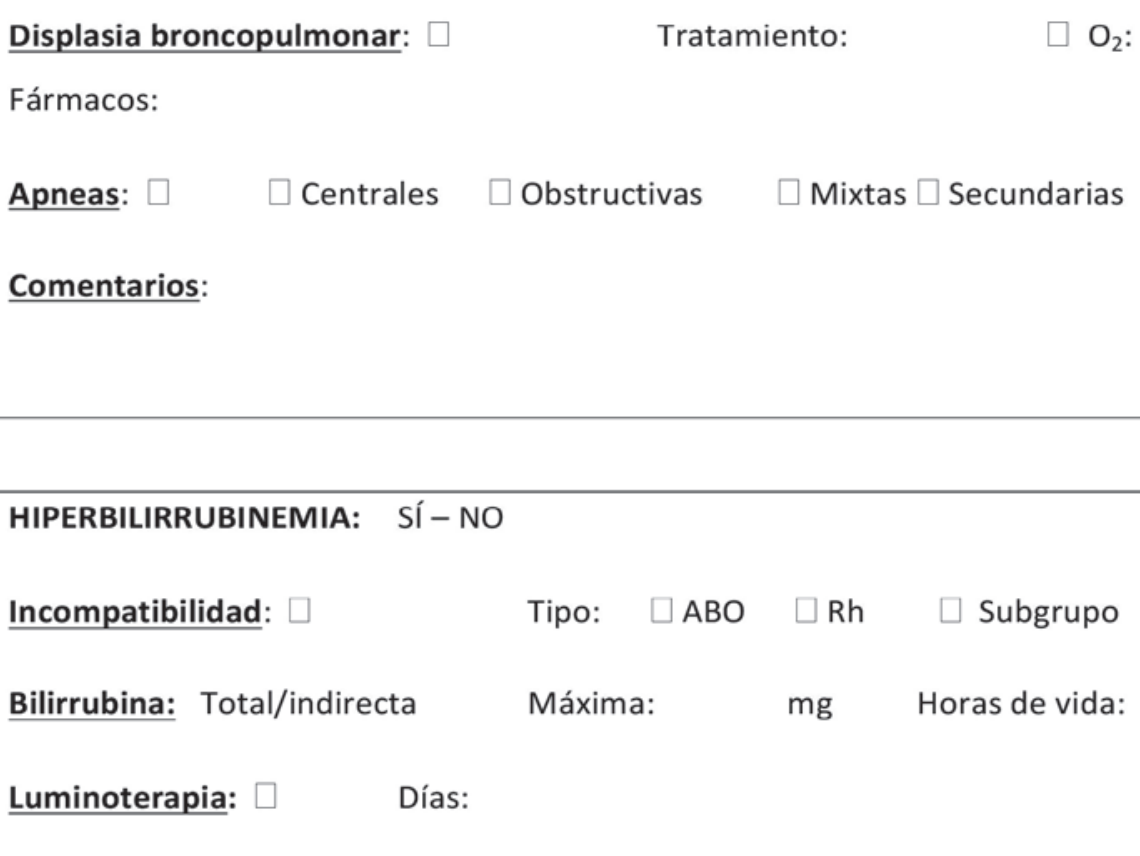

Displasia broncopulmonar:
Fármacos:
Apneas: $\square \quad \square$ Centrales $\quad \square$ Obstructivas
Comentarios:
HIPERBILIRRUBINEMIA: Sí - NO
Incompatibilidad: $\square \quad \square$ ABO
Bilirrubina: Total/indirecta $\quad$ Máxima:
Luminoterapia: $\square \quad$ Días:

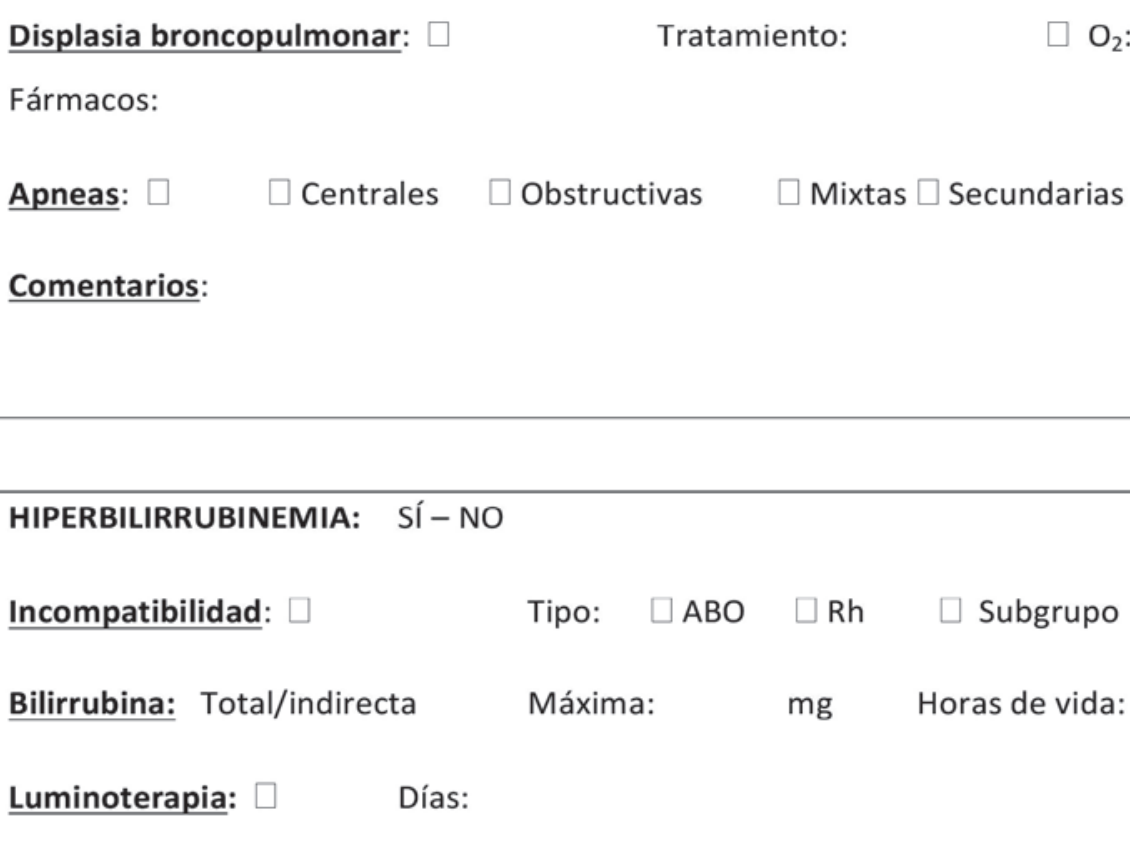

Displasia broncopulmonar:
Fármacos:
Apneas: $\square \quad \square$ Centrales $\quad \square$ Obstructivas
Comentarios:
HIPERBILIRRUBINEMIA: SÍ-NO
Incompatibilidad: $\square \quad \square$ ABO
Bilirrubina: Total/indirecta $\quad$ Máxima:
Luminoterapia: $\square \quad$ Días:

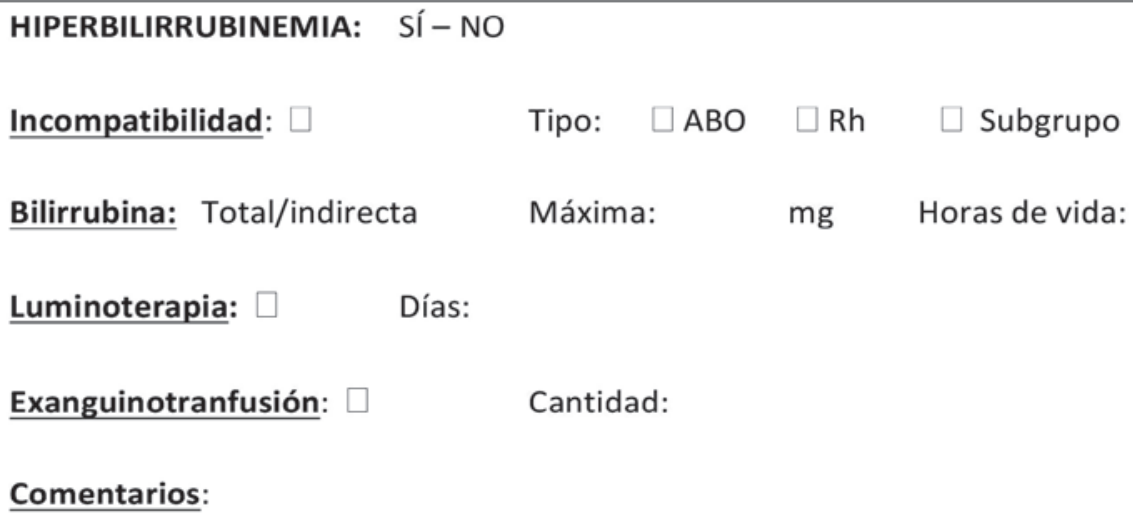

TRASTORNOS HEMATOLÓGICOS: SÍ - NO

Otras patologías: $\square$ CID $\square$ Plaquetopenia

$\square$ Trombosis $\square$ Hemorragias

Otras: 


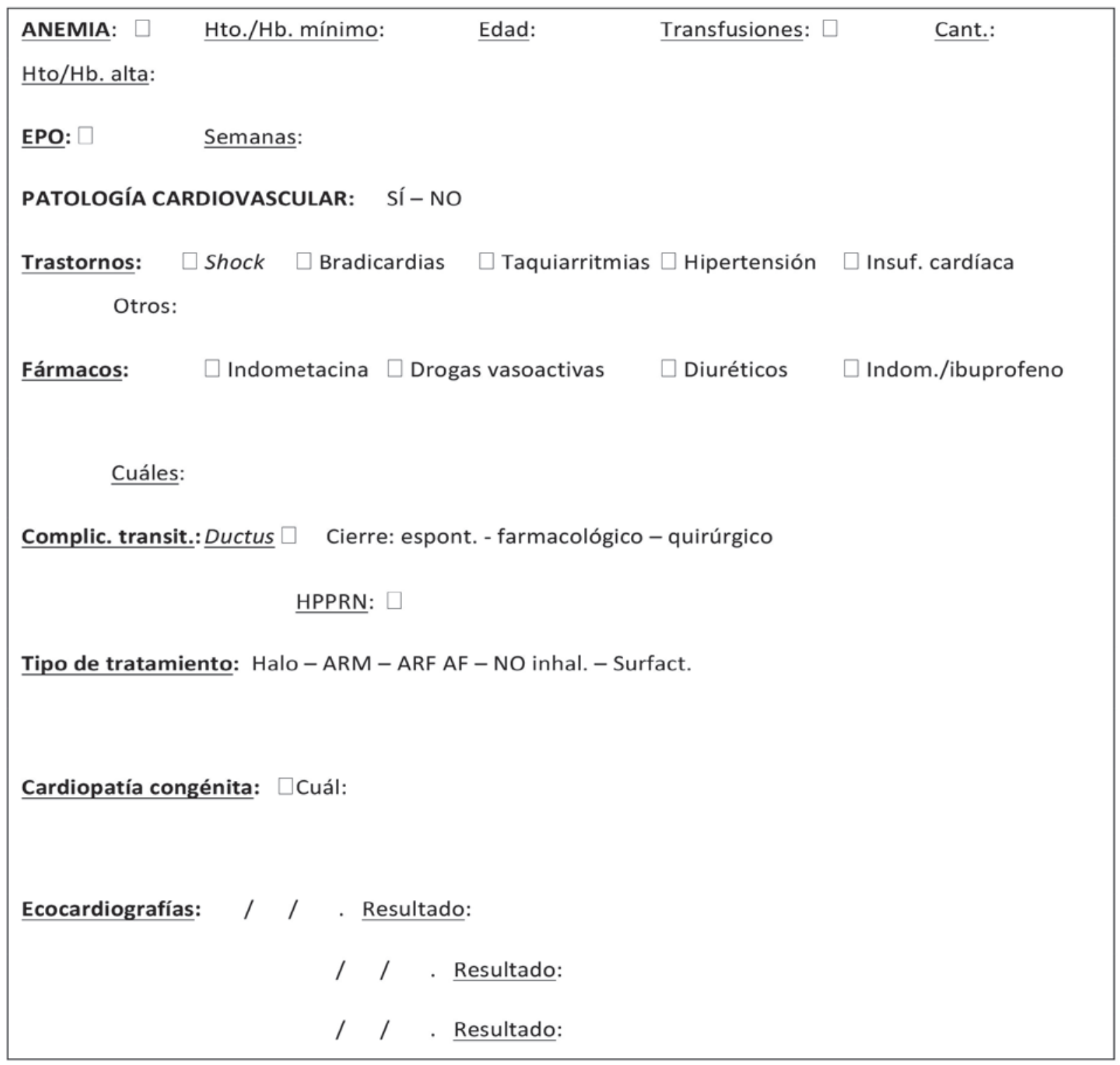

\section{INFECCIONES: SÍ - NO}

Tipo: $\square$ Connatal $\square$ Intranosocomial Cuál:

TORCHS: $\square$ Toxo. - $\square$ Rubéola - $\square$ Chagas - $\square$ Sífilis - $\square$ HIV Sospechada/confirmada

Sepsis: $\square \quad$ Temprana - Tardía Germen:

Comentarios: 


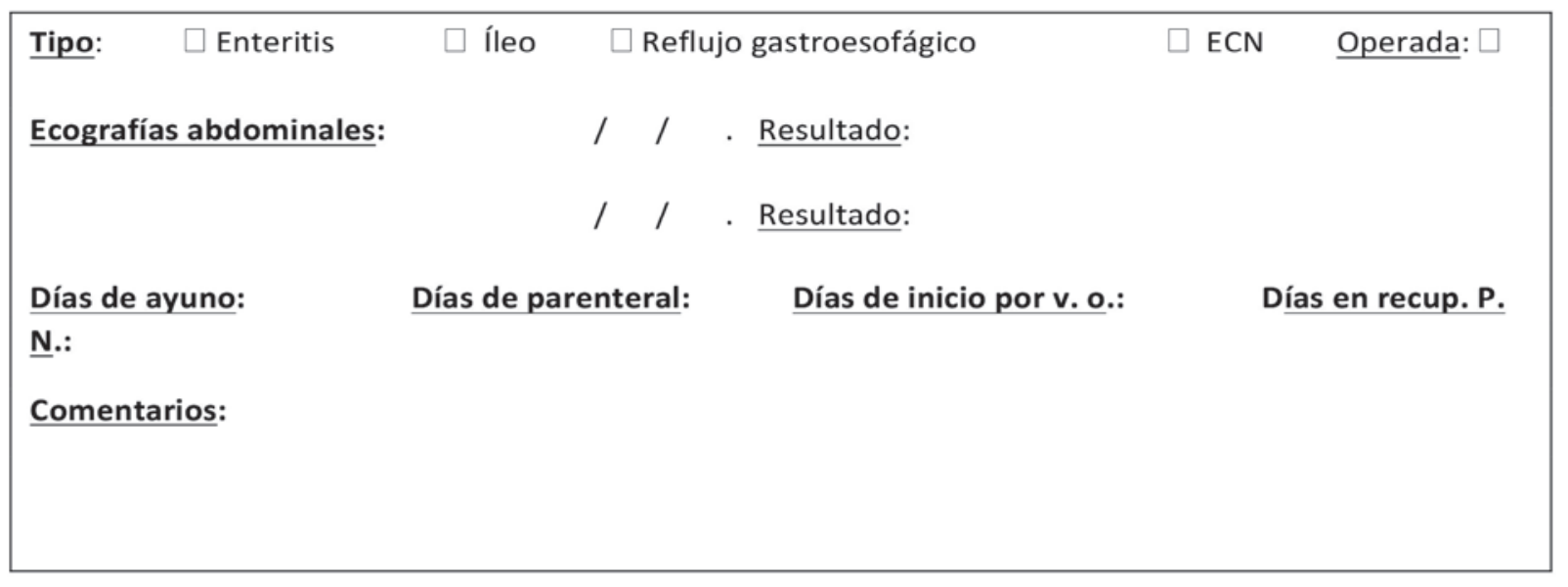

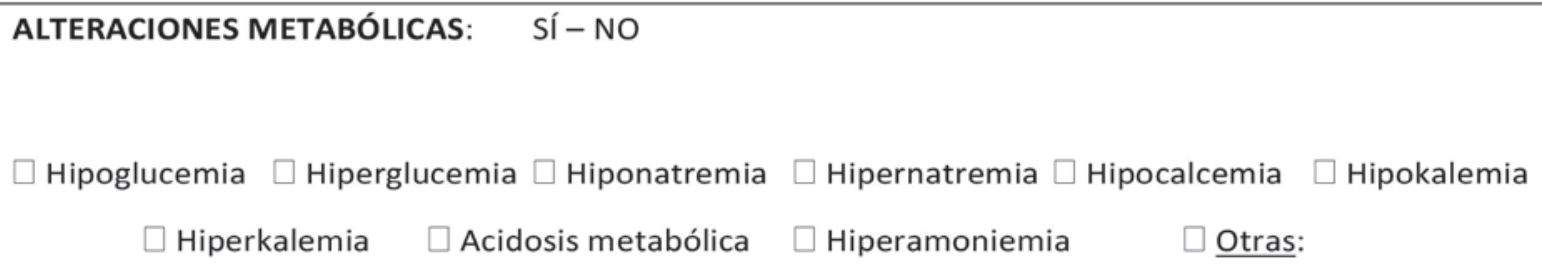

Comentarios:

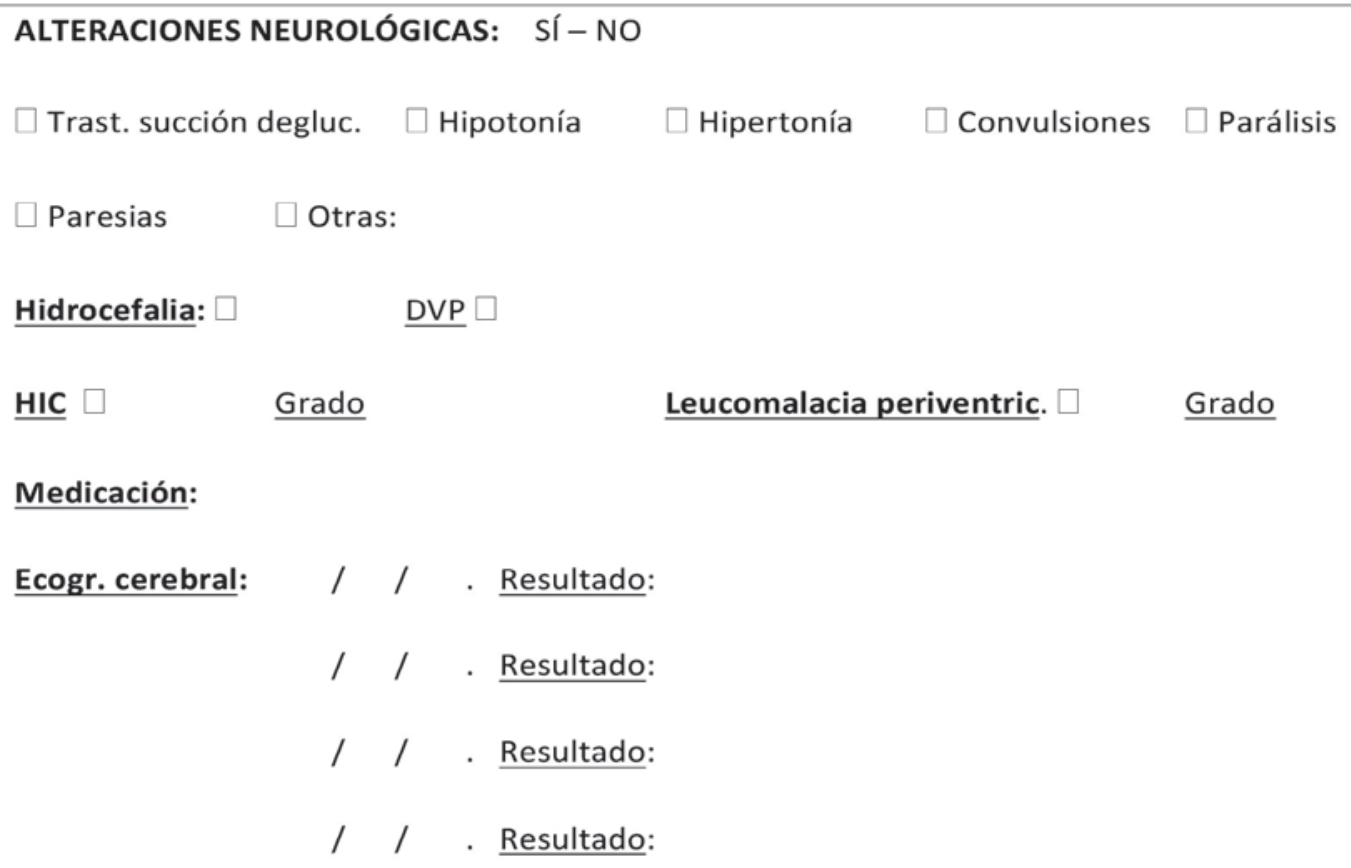

Ex. neurol. a las 40 semanas: Normal Dudoso Anormal

\section{Comentario:}




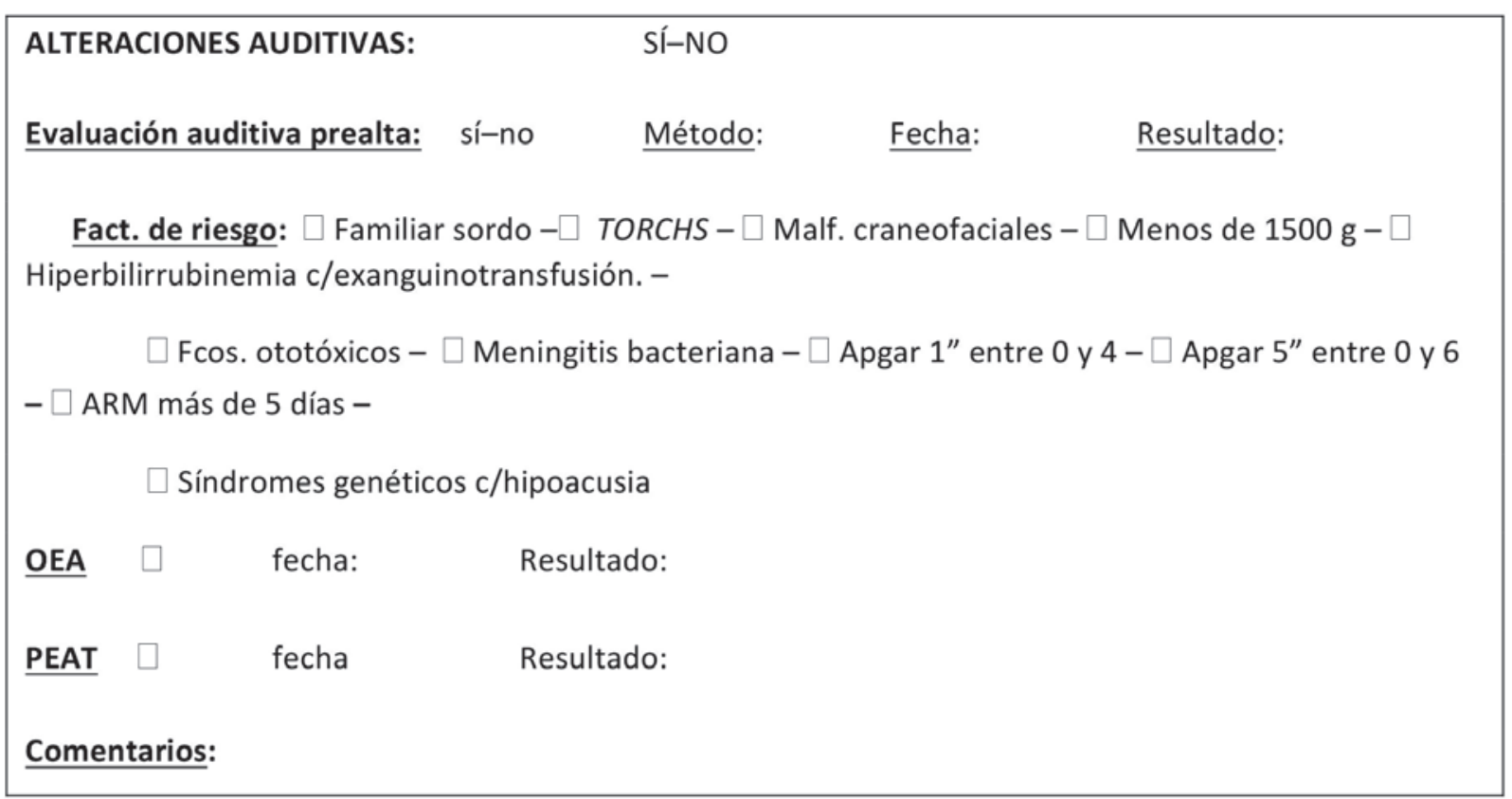

\section{ALTERACIONES VISUALES: SÍ-NO}

\begin{tabular}{|c|c|c|c|}
\hline Malformaciones $\square$ & Cuál: & & Cataratas: $\square$ \\
\hline \multicolumn{4}{|l|}{ rojo: $\square$} \\
\hline Ojo izq. ROP: & Grado & $\underline{\text { Plus: }} \square$ & Láser $\square$ Coment.: \\
\hline Ojo der. ROP: & $\underline{\text { Grado }}$ & $\underline{\text { Plus: }} \square$ & Láser $\square$ Coment.: \\
\hline
\end{tabular}

Controles: . $^{\text {ero }} /$ / . Result.:

$2^{\text {do }} \quad / \quad /$. Result.:

3. ${ }^{\text {ro }} \quad / \quad / \quad$. Result.:

$4^{\text {to }} \quad / \quad /$. Result.:

5. $^{\text {to }} \quad / \quad /$. Result.:

Fecha del próximo control:

Alta oftalmológica:

Comentarios: 


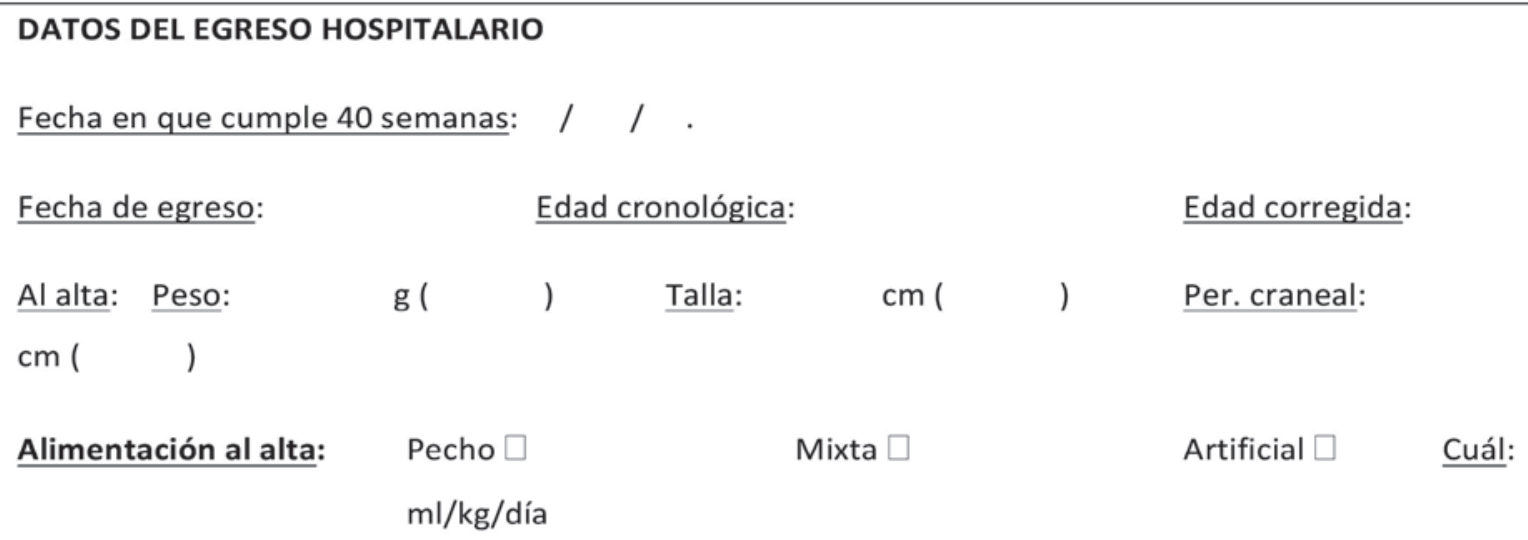

\section{Medicación al alta:}

\begin{tabular}{|c|c|c|}
\hline 1) & dosis & cada \\
\hline 2) & dosis & cada \\
\hline 3) & dosis & cada \\
\hline 4) & dosis & cada \\
\hline 5 & dosis & cada \\
\hline
\end{tabular}

\section{Otros tratamientos:}

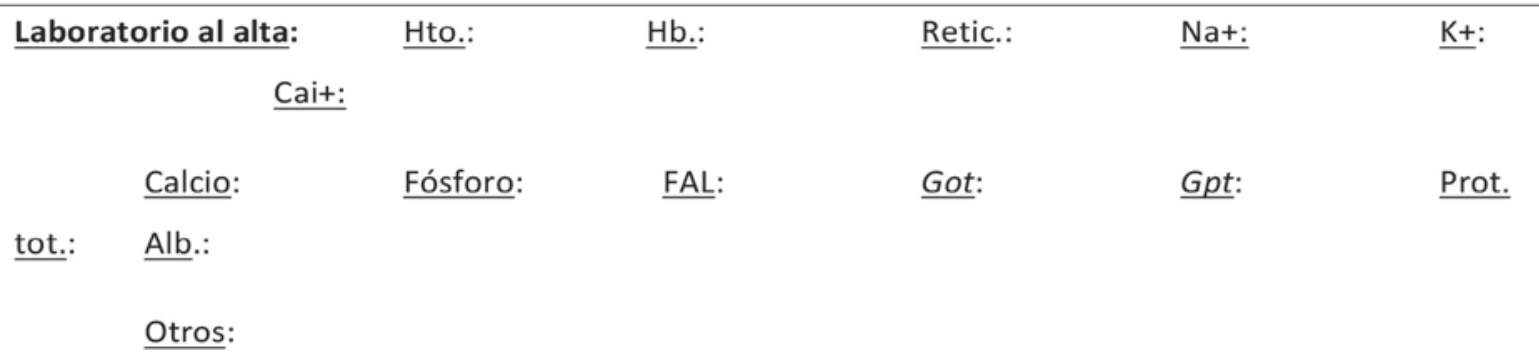

\section{Diagnósticos al egreso:}




\section{Estudios pendientes:}

I)

IV)

II)

v)

III)

VI)

Consideraciones iniciales del seguimiento y plan de estudios:

Fecha: / / . Firma y sello 


\section{EVOLUCIÓN}

Nombre y apellido:

H. C.:

FECHA / / Edad cronológica: Edad corregida:

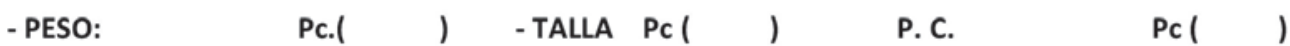

Estado de las vacunas:

Desarrollo neuromadurativo:

$\begin{array}{lllll}\text { Alimentación: } & \text { Pecho } \square \text { Mixta } \square \text { Fórmula } \square: \text { Tipo: } & & \\ \text { Cantidad: } & \text { ml. Cada: } \quad \text { h. Total: } & \mathrm{ml} / \mathrm{kg} / \text { dia. } & \text { Semisólidos } & \text { Sólidos } \\ \text { Suplementos: } & \square \text { Fe: } \quad \square \text { Fólico: } \square \text { ACD: } \square \text { Vit. D: } & \square \text { Calcio: } & \square \text { Fósforo: }\end{array}$

Otros:

¿Recibió información preventiva para la edad (accidentes, estimulación, etc.)?

\section{Examen físico (datos +):}

\section{Diagnóstico:}

Trae resultados de

Solicito lo siguiente para la próxima visita:

Tratamiento e indicaciones:

1)

4)
3)

6) 


\section{Ejemplos de patologías atendidas en Cuidados Especiales Ambulatorios Pediátricos}

- Grupo 1: Bronquitis obstructiva recurrente, enfermedad pulmonar obstructiva crónica posviral, bronquiectasias, absceso pulmonar, malformación adenoidea quística, tetralogía de Fallot, comunicación interventricular, ductus arterioso persistente, comunicación interauricular, miocardiopatía dilatada, retinitis pigmentaria, cataratas congénita, estrabismo grave, ambliopía, artritis reumatoidea juvenil, espondilitis anquilosante, focomelia, enfermedad celíaca, reflujo gastroesofágico grave, hipotiroidismo congénito y autoinmune, vitiligo, fiebre reumática, síndrome urémico hemolítico, síndrome nefrítico, síndrome nefrótico, reflujo vesicoureteral, agenesia renal, ureterocele.

- Grupo 2: Onfalocele, higroma quístico, fístula traqueoesofágica, fisura labio-alvéolo-palatina, atresia duodenal, membrana yeyunal, gastrosquisis, atresia de vías biliares, síndrome de Alagille, cavernoma de la vena porta, enfermedad de Hirschsprung.

- Grupo 3: Down, Klinefelter, Stickler, Williams, Sotos, neurofibromatosis 1, Prader-Willi, fragilidad del cromosoma X, Poland, Sturge-Weber, asociación VATER, alcoholismo fetal, osteogénesis imperfecta, displasia cleidocraneal, discrepancia de miembros, craneosinostosis (Apert, Pfeiffer, trigonocefalia), mielomeningocele, lipoma de raquis, Dandy-Walker, artrogrifosis, diabetes tipo I y II, hipercolesterolemia familiar.

- Grupo 4: Hipoacusia neurosensorial, encefalopatía crónica no evolutiva, diplejía espástica, epilepsia, hidrocefalia, distrofia de Duchenne, retraso madurativo, retraso mental, trastornos de aprendizaje, trastorno generalizado del desarrollo, parálisis cerebral.

- Grupo 5: Leucemia linfoblástica aguda, retinoblastoma, linfoma, craneofaringioma, tumor de órbita, tumor de tálamo.

- Grupo 6: Prematurez extrema, bajo peso y muy bajo peso al nacer, infecciones congénitas (sífilis, toxoplasmosis, citomegalovirus, chagas, HIV, rubéola), retinopatía del prematuro. 